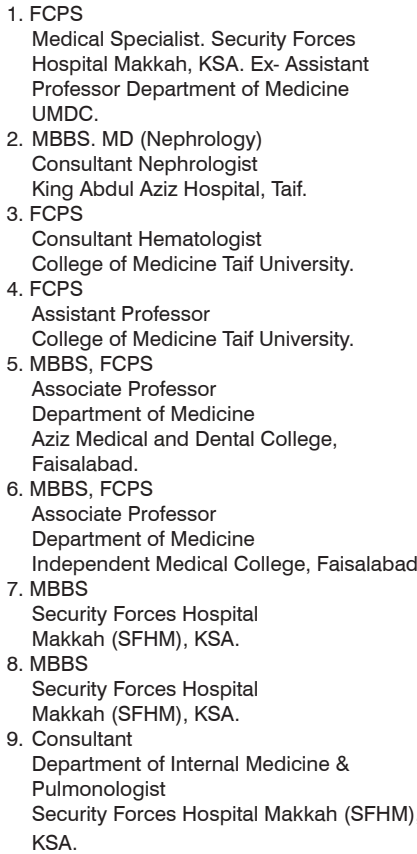

Correspondence Address:

Dr. Imran Nazir Ahmad

278- Jinnah Colony Faisalabad.

Pakistan.

imrannazir40@gmail.com

Article received on:

09/04/2019

Accepted for publication:

29/07/2019

\section{INFLUENZA A H1N1 CHARACTERISTICS ON HAJJ OCCASION 2018 MAKKAH REGION, KSA.}

Imran Nazir ${ }^{1}$, Muhammad Ajmal Farid ${ }^{2}$, Hammad Tufail Chaudhary ${ }^{3}$, Iffat Imran ${ }^{4}$, Rizwan Rasul Khan $^{5}$, Ali Saqib ${ }^{6}$, Ahmad Turkistani ${ }^{7}$, Ahmad Asiri ${ }^{8}$, Abdullah Swida ${ }^{9}$

\begin{abstract}
Objectives: To see the clinical characteristics and laboratory parameters of influenza A (H1N1) infection on hajj occasion 2018. Introduction: World Health Organization in 2009 declared $\mathrm{H} 1 \mathrm{~N} 1$ as pandemic, when about 70 countries documented approximately 30,000 cases of $\mathrm{H} 1 \mathrm{~N} 1$ infection. Saudi Arabia is representing a hot zone for influenza virus epidemics especially during Hajj gathering. Commonly $\mathrm{H} 1 \mathrm{~N} 1$ infection presents with flue like symptoms. Influenza infection is a major public health threat especially area like Makkah. Study Design: It was observational study. Setting: Done in Security Forces Hospital Makkah. Period: On hajj occasion from July to August 2018. Material and Methods: Total 50 admitted patients in isolation were included in study. Data was collected and analyzed using SPSS version 24. Results: In this study $08 \%$ patients had $\mathrm{H} 1 \mathrm{~N} 1$ + ve out of total patients included in study. Predominantly $(75 \%)$ were $<14$ years with $75 \%$ males. The most common presenting symptoms of these patients were Cough (100\%), Fever (100\%), breathlessness (75\%), throat pain $(50 \%)$, runny nose $(75 \%)$, headache and lethargy $(50 \%)$. Twenty five percent patients had hypoxia. Leukopenia was seen in $50 \%$ patients and thrombocytopenia was not documented in any patient. Liver Function Tests were deranged in $75 \%$ patients and Renal Function Tests were normal in all patients. Number of complications (pneumonia) was 25\%. Conclusion: Clinical features and serological markers of influenza A + ve patients were same as reports globally and in KSA.

Key words: $\quad$ Clinical Features, HINI, KSA, Serological Characters.

Article Citation: Nazir I, Farid MA, Chaudhary HT, Imran I, Khan RR, Saqib A, Turkistani A, Asiri A, Swida A. Influenza a H1N1 characteristics on hajj occasion 2018 Makkah Region, KSA. Professional Med J 2019; 26(11):1993-1997. DOI: 10.29309/TPMJ/2019.26.11.3900
\end{abstract}

\section{INTRODUCTION}

H1N1 was declared by the World Health Organization (WHO) in 2009 as pandemic. When about 70 countries documented $\mathrm{H} 1 \mathrm{~N} 1+$ ve cases about $30,000 .^{1,2} \mathrm{H} 1 \mathrm{~N} 1$ pandemic globally caused deaths about $575,400 .^{3}$

Saudi Arabia is representing a hot zone for influenza epidemics, due to the Hajj gathering. ${ }^{4}$ Human infection with influenza virus is expected through human-to-human transmission especially during Hajj gatherings where peoples are visiting from different countries and different climates.

Common clinical presentation of influenza infection is fever, cough, dyspnea, myalgia, headache and upper respiratory symptoms.
Commonly cases has mild symptoms and selflimited, although small percentage of patients have a severe course that may end in respiratory failure and death. ${ }^{5}$ Such severe course and fatal outcome is more in patients with concomitant chronic diseases. Sometimes seen in previously healthy people. ${ }^{6}$ Bacterial pneumonia is expected as secondary complications of $\mathrm{H} 1 \mathrm{~N} 1$ infection. $^{7}$

Rapid and sensitive diagnostic tests for influenza is an important tool that is considered in future influenza pandemic planning. ${ }^{8}$

Final diagnosis of $\mathrm{H} 1 \mathrm{~N} 1$ infection depends on Clinical decision and influenza RT-PCR in any setting. ${ }^{9}$ 
Ministry of Health KSA, declared 15850 laboratoryconfirmed cases of $\mathrm{H} 1 \mathrm{~N} 1$ in 2009. ${ }^{10}$

Few studies (Altayep KM et al. ${ }^{4}$, Agha A et al. ${ }^{11}$, Herzallah HK et al. ${ }^{12}$, Affifi RM et al. ${ }^{13}$, Bin Saeed AA et al. ${ }^{14}$ ) done for H1N1 from whole Saudi Arabia.

In 2009 Khdary et al ${ }^{15}$ did study in Makkah (data collected from primary health centers of $\mathrm{MOH}$. A total of 1138 patients were included in the study. Among the study population, $\mathrm{H} 1 \mathrm{~N} 1$ positive case were $25 \%$.

Influenza is a major public health threat especially area like Makkah. Annually millions of pilgrims are coming from different regions of World.

So this study was conducted in tertiary Hospital of Makkah, where more sick patients are visiting. It described the epidemiology, clinical and laboratory parameters of influenza $A(\mathrm{H} 1 \mathrm{~N} 1)$ infection on hajj occasion among residents, citizens, pilgrims and military personals in Makkah city during 2018.

\section{MATERIALS AND METHODS}

This was a prospective observational study that was carried out at security Forces Hospital at Hajj occasion 2018 after institutional ethical committee approval.

All patients admitted in isolation were included in study according to following inclusion criteria;

1. Both sexes.

2. Admitted in isolation with case definition of ILI (influenza like illness); fever of $>38 \mathrm{c}$, cough with illness onset within the last 10 days.

3. Pregnant patients.

Exclusion criteria was:

1. Patients with active malignancy with cancer therapy.

2. Patients with organ transplant with immunosuppressive therapy.

All patients were reviewed regarding their clinical features, clinical signs and laboratory parameters after patients consent and stratified random sampling technique was adopted. All patients were initially screened by serological methods and confirmed positive for novel influenza through Real Time Polymerase Chain Reaction (RT-PCR) testing via nasal and throat swabs.

Data were collected and analyzed using a Microsoft Excel and Statistical Package for Social Sciences (SPSS version 24).

\section{RESULTS}

The incidence of $\mathrm{H} 1 \mathrm{~N} 1$ positive patents was $08 \%$ in all admitted patients in isolation.

In this study age of the patients ranges from 2 years to 63 years $(75 \%<14$ years) with $75 \%$ males and $25 \%$ females (Table-I). Hundred percent patients were citizens of Saudi Arabia. The most common presenting symptoms of these patients were fever (100\%), cough (100\%), breathlessness (75\%), throat pain $(50 \%)$, runny nose $(75 \%)$, headache and lethargy (50\%) as shown in Table-Il.

Twenty five percent patients had comorbid condition like Diabetes Mellitus, Chronic kidney disease, ischemic heart disease, old ischemic stroke and bed ridden.

Twenty five percent $\mathrm{H} 1 \mathrm{~N} 1$ positive patients had hypoxia and $25 \%$ had anemia. Leukopenia was seen in 50\% patients and thrombocytopenia was not documented in any patient.

Liver Function Tests were deranged in $75 \%$ patients and Renal Function Tests were normal in all patients as shown in Table-III.

Blood culture and sputum culture were negative in all patients. Twenty five percent $(25 \%)$ patients suffered from pneumonia but there was no death reported in these $\mathrm{H} 1 \mathrm{~N} 1+$ ve patients and all patients were improved. 


\begin{tabular}{|c|c|c|c|c|c|}
\hline \multicolumn{2}{|c|}{ Demo-graphics } & Years & $\begin{array}{l}\text { H1N1 } \\
\text { Positive }\end{array}$ & $\begin{array}{c}\text { H1N1 } \\
\text { Negative }\end{array}$ & Total \\
\hline \multirow{4}{*}{\multicolumn{2}{|c|}{$\begin{array}{l}\text { Age groups } \\
\text { by years }\end{array}$}} & $0-14$ & 3 & 0 & 03 \\
\hline & & $15-40$ & 0 & 17 & 17 \\
\hline & & $41-60$ & 0 & 9 & 09 \\
\hline & & $>60$ & 1 & 20 & 21 \\
\hline \multirow{2}{*}{\multicolumn{2}{|c|}{ Gender }} & Male & 3 & 23 & 26 \\
\hline & & Female & 1 & 23 & 24 \\
\hline \multirow{2}{*}{\multicolumn{2}{|c|}{ Co-morbidity }} & No & 3 & 23 & 26 \\
\hline & & Yes & 1 & 23 & 24 \\
\hline \multirow{2}{*}{\multicolumn{2}{|c|}{ Complications }} & No & 3 & 28 & 31 \\
\hline & & Yes & 1 & 18 & 19 \\
\hline \multirow{2}{*}{\multicolumn{2}{|c|}{ Outcome }} & mproved & 4 & 46 & 50 \\
\hline & & Death. & 0 & 0 & 0 \\
\hline \multicolumn{6}{|c|}{$\begin{array}{l}\text { Table-I. Demographic features and outcome of H1N1 } \\
\text { +VE \& H1N1 -VE cases: }\end{array}$} \\
\hline \multicolumn{2}{|c|}{ Clinical Features } & \multicolumn{2}{|c|}{$\begin{array}{l}\text { H1N1 } \\
\text { Positive }\end{array}$} & $\begin{array}{c}\text { H1N1 } \\
\text { Negative }\end{array}$ & Total \\
\hline \multirow{2}{*}{ Fever; } & No & \multicolumn{2}{|c|}{0} & 6 & 6 \\
\hline & Yes & \multicolumn{2}{|c|}{4} & 40 & 44 \\
\hline \multirow{2}{*}{ Cough: } & No & \multicolumn{2}{|c|}{0} & 02 & 02 \\
\hline & Yes & \multicolumn{2}{|l|}{4} & 44 & 48 \\
\hline \multirow{2}{*}{ SOB: } & No & \multicolumn{2}{|c|}{1} & 04 & 05 \\
\hline & Yes & \multicolumn{2}{|c|}{3} & 42 & 45 \\
\hline \multirow{2}{*}{$\begin{array}{l}\text { Running } \\
\text { Nose: }\end{array}$} & No & \multicolumn{2}{|l|}{1} & 46 & 47 \\
\hline & Yes & \multicolumn{2}{|l|}{3} & 0 & 03 \\
\hline \multirow{2}{*}{$\begin{array}{l}\text { Sore } \\
\text { Throat; }\end{array}$} & No & \multicolumn{2}{|c|}{2} & 37 & 39 \\
\hline & Yes & \multicolumn{2}{|c|}{2} & 9 & 11 \\
\hline \multirow{2}{*}{$\begin{array}{l}\text { Headache/ } \\
\text { lethargy: }\end{array}$} & No & \multicolumn{2}{|c|}{2} & 42 & 44 \\
\hline & Yes & \multicolumn{2}{|c|}{2} & 04 & 06 \\
\hline $\begin{array}{l}\text { Nausea/ } \\
\text { vomiting: }\end{array}$ & No & \multicolumn{2}{|l|}{4} & 46 & 50 \\
\hline $\begin{array}{l}\text { Loose } \\
\text { stools: }\end{array}$ & No & \multicolumn{2}{|l|}{4} & 46 & 50 \\
\hline
\end{tabular}

Table-II. Symptoms in H1N1 positive versus negative cases.

\begin{tabular}{|c|c|c|c|c|}
\hline \multicolumn{2}{|c|}{ Laboratory Parameters } & \multirow{2}{*}{$\begin{array}{c}\begin{array}{c}\text { H1N1 } \\
\text { Positive }\end{array} \\
3\end{array}$} & \multirow{2}{*}{$\begin{array}{c}\begin{array}{c}\text { H1N1 } \\
\text { Negative }\end{array} \\
42\end{array}$} & \multirow{2}{*}{$\begin{array}{r}\text { Total } \\
45\end{array}$} \\
\hline $\begin{array}{l}\text { Hb. } \\
\text { Anemia: }\end{array}$ & No & & & \\
\hline & Yes & 1 & 4 & 05 \\
\hline \multirow[t]{3}{*}{ Wbcs: } & Leukopenia. & 2 & 0 & 02 \\
\hline & $\begin{array}{l}\text { Normal } \\
\text { leukocytes }\end{array}$ & 1 & 8 & 09 \\
\hline & Leukocytosis & 1 & 38 & 39 \\
\hline \multirow[t]{2}{*}{ Platelets: } & $\begin{array}{l}\text { Thrombocy- } \\
\text { topenia }\end{array}$ & 0 & 2 & 02 \\
\hline & $\begin{array}{l}\text { Normal } \\
\text { platelets }\end{array}$ & 4 & 44 & 48 \\
\hline \multirow[t]{2}{*}{ LFTS. } & Normal & 1 & 42 & 42 \\
\hline & Abnormal & 3 & 4 & 08 \\
\hline \multirow[t]{2}{*}{ RFTS. } & Normal & 4 & 42 & 46 \\
\hline & Abnormal & 0 & 4 & 04 \\
\hline \multirow[t]{2}{*}{ Spo2. } & Normal & 3 & 32 & 35 \\
\hline & Abnormal & 1 & 14 & 15 \\
\hline
\end{tabular}

Table-III. Laboratory investigation in $\mathrm{H} 1 \mathrm{~N} 1$ positive VS H1N1 negative patients.

\section{DISCUSSION}

It was an observational study of 50 cases that were admitted according to ILI (influenza like illness) definition and $\mathrm{MOH}$ (ministry of health) criteria.

H1N1+ve patients clinical presentation varied from subclinical illness to severe respiratory failure and resemble those observed in patients with seasonal influenza. ${ }^{16,17,18}$ Some clinical features of $\mathrm{H} 1 \mathrm{~N} 1+$ ve patients are different from those of seasonal influenza, such as younger age and less comorbidity. ${ }^{19}$

The clinical features (fever, cough, sore throat, headache, lethargy) of $\mathrm{H} 1 \mathrm{~N} 1$-positive patients were almost similar to that of $\mathrm{H} 1 \mathrm{~N} 1$ negative patients. Because of ILI criteria.

Climate has effect on $\mathrm{H} 1 \mathrm{~N} 1$ infection percentage. More cases were seen in the fall than in the summer season in KSA in previous study. ${ }^{20}$

In our study the number of $\mathrm{H} 1 \mathrm{~N} 1$ positive patients are less than previous years. ${ }^{15}$ This can be 
due to patients of only KSA residents (100\%), vaccination status and seasonal variation. ${ }^{20}$ The distribution of cases by age were predominantly young (75\% < 14 years), that are almost similar to the distribution of cases observed worldwide and in Saudi Arabia. ${ }^{10,15,20}$

So, the clinical parameters were generally similar as the earlier reported cases of influenza in $\mathrm{KSA}^{10,15}$ and USA. ${ }^{20}$

All patients in our study presented with fever and cough, which is almost similar to the patients in USA, ${ }^{20}$ Japan, ${ }^{21}$ Mexico. ${ }^{22}$ and in KSA. ${ }^{10,15}$

Leukopenia was observed in $50 \%$ patients and thrombocytopenia was found $(0 \%)$, that was almost similar as in earlier studies. ${ }^{10,15,20}$

Patients found to be hypoxemic (25\%) had an average oxygen saturation of $88 \%$. Currently literature shows that clinically severity of disease can be judged by dyspnea presence. ${ }^{23}$

In our study, the fatality rate was $0 \%$ as almost seen in USA and the United Kingdom. ${ }^{20}$

All our studied patients received Oseltamivir, and antibiotics on admission. Bacterial cultures in sputum or blood did not show significant growth and then antibiotics were stopped.

IDSA recommend the early use of antiviral drugs in patients who need hospitalization following influenza. Even antiviral therapy within 48 hours is the recommended.

This study was not without limitations. In our study the number of cases were small, was single centered experience, all patients were Saudi residents and vaccination status of patients was not evaluated.

\section{CONCLUSION}

Mostly patients presented with mild respiratory disease. Clinical features and serological characteristics of influenza positive patients were same as reports globally and in KSA.

Early antiviral therapy in patients with influenza infection is recommended.
Health education and public awareness regarding safety precautions are important pillars in addition to surveillance, mandatory vaccination and early provision of diagnostic facilities.

Large Multicenter studies are required for further evaluation.

Copyright@ 29 July, 2019.

\section{REFERANCES}

1. Rewar S, Mirdha D, Rewar P. Treatment and prevention of pandemic H1N1 influenza. Ann Glob Health2015; 81: 645-53. [PubMed].

2. Fineberg HV. Pandemic preparedness and response lessons from the $\mathrm{H} 1 \mathrm{~N} 1$ influenza of 2009. N Engl J Med 2014; 370: 1335-42. [PubMed].

3. Dawood FS, luliano AD, Reed C, et al. Estimated global mortality associated with the first 12 months of 2009 pandemic influenza $A$ H1N1 virus circulation: $A$ modelling study. Lancet Infect Dis 2012; 12: 687-95. [PubMed].

4. Altayep KM, Ahmed HG, Tallaa AT, Alzayed AS, Alshammari AJ, Talla ATA. Epidemiology and clinical complication patterns of influenza A (H1N1 Virus) in Northern Saudi Arabia. Infect Dis Rep. 2017 May 31; 9(2): 6930.Available from: doi:10.4081/idr.2017.6930.

5. Ajlan AM, Quiney B, Nicolaou S, Müller NL. Swine-origin influenza A (H1N1) viral infection: Radiographic and CT findings. AJR 2009; 193:1494-1499.

6. Elicker BM, Schwartz BS, Liu C, et al. Thoracic CT findings of novel influenza $A$ (H1N1) infection in immunocompromised patients. Emerg Radiol 2010; 17:299-307.

7. Cunha BA, Corbett M, Mickail N. Human parainfluenza virus type 3 (HPIV 3) viral community-acquired pneumonia (CAP) mimicking swine influenza (H1N1) during the swine flu pandemic. Heart Lung2011; 40: 76-80. [PubMed].

8. Mahony $\mathrm{AA}$, Cheng $\mathrm{AC}$, Olsen $\mathrm{KL}$, Aboltins $\mathrm{CA}$, Black JFB, Johnson PDR. Diagnosing swine flu: The inaccuracy of case definitions during the 2009 pandemic, an attempt at refinement, and the implications for future planning. Influenza journal. Available from DOI:10.1111/j.1750-2659.2012. 00398.x.

9. Bin Saeed AA, Siddiqui AR, Mandil AM, Torchyan AA, Tayel SA, Shaikh SA et all. The role of rapid testing and clinical decision in the diagnosis of human influenza A H1N1 infection. Saudi Med J 2014; Vol. 35 (3): 277-284. 
10. Al Mazroa MA, Memish ZA, AlWadey AM. Pandemic influenza $A$ (H1N1) in Saudi Arabia: description of the first one hundred cases. Ann Saudi Med. 2010 JanFeb; 30(1): 11-14.Available from: doi: 10.4103/02564947.59366 .

11. Agha A, Alrawi A, Munayco CV, AlAyed MS,Al-Hakami $M$, Korairi $H$, et all. Characteristics of patients hospitalized with 2009 H1N1 influenza in a Tertiary Care Hospital in Southern Saudi Arabia. Mediterr J Hematol Infect Dis. 2012; 4(1): e2012002.Available from: doi: 10.4084/ MJHID.2012.002.

12. Herzallah HK, Bubshait SA, Antony AK, Al-Otaibi ST. Incidence of influenza A H1N1 2009 infection in Eastern Saudi Arabian hospitals. Saudi Med J 2011; 32:598 -602. [PubMed].

13. Affifi RM, Omar SR, El Raggal AA. A novel influenza A (H1N1) outbreak experience among residents of a long term-care facility in Saudi Arabia during 2010 seasonal flu circulation. Infect Dis Rep2012; 4: e 23.

14. Bin Saeed AA. Characteristics of pandemic influenza A (H1N1) infection in patients presenting to a university hospital in Riyadh, Saudi Arabia. Ann Saudi Med 2010; 30:59-62.

15. Khdary $\mathrm{NH}$, Alalem MA, Turkistan AM, Alghamdi SS. An epidemiological study on influenza A (H1N1) in Makkah. Advances in infectious diseases, 2014, 4,198-206. Available from: http://dx.doi.org/10.4236/ aid.2014.44028.

16. Jain S, Kamimoto L, Bramley AM, Schmitz AM, Benoit SR, Louie J, et al. Hospitalized patients with 2009 H1N1 influenza in the United States, April-June 2009. N Engl J Med. 2009; 361: 1935 -1944.
17. Dawood FS, Jain S, Finelli L, Shaw MW, Lindstrom S, et al. Emergence of a novel swine-origin influenza A (H1N1) virus in humans. N Engl J Med. 2009; 360: 2605-2615.

18. Chowell G, Bertozzi SM, Colchero MA, Lopez-Gatell $H$, Alpuche-Aranda C, Hernandez M, et al. Severe respiratory disease concurrent with the circulation of H1N1 influenza. N Engl J Med. 2009; 361:674 -679.

19. Riquelme R, Torres A, Rioseco ML, Ewig S, Cillóniz C, Riquelme $M$, et al. Influenza pneumonia: A comparison between seasonal influenza virus and the H1N1 pandemic. Eur Respir J. 2011; 38:106-111.

20. Al-Tawfiq JA, Abed M, Saadeh BM, Ghandour J, Shaltaf M, Babiker MM. Pandemic influenza A (2009 H1N1) in hospitalized patients in a Saudi Arabian Hospital: Epidemiology and clinical comparison with H1N1negative patients. Indian J Crit Care Med. 2017 Dec; 21(12): 811-818. doi:10.4103/ijccm.IJCCM_324_17.

21. Human infection with new influenza $A(\mathrm{H} 1 \mathrm{~N} 1)$ virus: Clinical observations from a school-associated outbreak in Kobe, Japan, May 2009. Wkly Epidemiol Rec 2009. Jun; 84 (24):237-244.

22. Human infection with new influenza $A(\mathrm{H} 1 \mathrm{~N} 1)$ virus: Clinical observations from Mexico and other affected countries, May 2009. Wkly Epidemiol Rec 2009. May; 84 (21):185-189.

23. World Health Organization. WHO guidelines for pharmacological management of pandemic (H1N1) 2009 influenza and other influenza viruses. Geneva: 2010. at:http://www.who.int/csr/resources/publications/ swineflu/h1n1_use_antivirals_20090820/en/index.html.

\begin{tabular}{|c|c|c|c|}
\hline \multicolumn{4}{|c|}{ AUTHORSHIP AND CONTRIBUTION DECLARATION } \\
\hline Sr. \# & Author(s) Full Name & Contribution to the paper & Author(s) Signature \\
\hline 1 & Imran Nazir Ahmad & Main Author & \\
\hline 2 & M. Ajmal Farid & Co-author & \\
\hline 3 & $\begin{array}{l}\text { Hammad Tufail } \\
\text { Chaudhary }\end{array}$ & Co-author & \\
\hline 4 & Iffat Imran & Co-author & \\
\hline 5 & Rizwan Rasul Khan & Co-author & \\
\hline 6 & Ali Saqib & Co-author & \\
\hline 7 & Ahmad Turkistani & Co-author & \\
\hline 8 & Ahmad Asiri & Co-author & \\
\hline 9 & Abdullah Swida & Co-author & a \\
\hline
\end{tabular}

